\title{
THE ROLE OF CONGRESS IN CONTRACT TERMINATION
}

\author{
Bertram M. Gross*
}

The invasion of Poland by the Nazis had a profound effect on the operations of the United States Congress. The emergent war situation of 1939 called for quick, decisive action of a type that could be forthcoming only from the executive branch of the Government. The trend toward the growing dominance of the executive, so apparent during the days of the Depression and the Recovery, became accentuated. Somewhat reluctant, sometimes protesting, Congress took a back seat. Between 1939 and 1943 , a growing volume of the basic decisions on national policy was made in the White House. Even the key legislative measures of the war-such as the War Powers Acts, the Lend-Lease Act, the Selective Service Act, the Emergency Price Control Act and the War Appropriations-were all initiated in the executive branch, drafted in the executive branch and passed with only insignificant alterations by Congress.

The pendulum is now swinging in the other direction. As war production reaches its peak and as we can already see victory in our grasp, the people of the country are looking increasingly to their elected representatives in the United States Congress to determine basic national policies during the transition period from war to peace and in the post-war world. On many fronts and in varying degrees, the members of the Congress have already started to take the initiative. Standing and special committees of the Congress, in addition to continuing the various in. vestigatory functions that have often contributed greatly to the administration of the war by the executive agencies, are in the process of drafting new legislation. The heads of executive departments and agencies are now increasingly coming to Congress for consultation on policy determinations or to ask for legislation.

It is against this background that one must appraise the role of the Congress in contract termination. In fact, the recent history of legislative proposals on contract termination well illustrates the rapidity with which the pendulum has swung.

In May, 1943, except for a few rare letters from troubled constituents, there was

-A.B., 1933, A.M., 1935, University of Pennsylvania; Staff Director, War Contracts Subcommittec, Senate Committee on Military Affairs; Chief of Research and Hearings, Senate Committec on Small Business, 1942-43; United States Housing Authority, I938-41; formerly Lecturer on Housing Economics, Graduate School, Department of Agriculture.

The views herein expressed are not necessarily those of the War Contrats Subcommittee or of any of its members. 
little interest in contract termination on Capitol Hill. In June, I943, the War Department drew up a brief bill extending. the powers of its contracting officers to make advance payments against terminated contracts. The War Department had no serious thought at that time of legislation covering any more than $2 \%$ of the subject or even going beyond the immediate needs of the War Department itself. Its bill was drawn up as a rider to the Department's appropriations bill then pending in the Congress, and it was the hope of the Department that it would go through quickly, without much ado. Hearings were held before the House Committee on Military Affairs on June 23, 24, 25, and 29, 1943. Members of the Committee, however, sensed the importance of the subject and decided to proceed warily. The bill was assigned to a subcommittee for study. Its introduction, however, had awakened new interest in the subject. Senator James E. Murray, Chairman of the Senate Committee on Small Business, realizing that the subject was one of profound import to thousands of small businessmen engaged on war contracts, introduced a measure extending the provisions of the War Department's bill to the other agencies and at the same time providing for uniformity of operation under the Chairman of the War Production Board. A few days later, a second version of the first House bill was introduced by Senator Robert Reynolds, Chairman of the Senate Committee on Military Affairs. Both bills were referred to the Senate Committee on Military Affairs. On July 18, 1943, Senator Murray made a preliminary report on the subject to the Senate Committee on Small Business, suggesting legislation that would require the procurement agencies to make mandatory advance payments amounting to at least $75 \%$ of their claim to prime contractors and subcontractors within 30 days after the submission of their claims. In this report Senator Murray pointed out that there were many important aspects of the contract termination problem which he had not yet studied, "such as the terms of final settlement, the amount of severance pay granted employees, the disposal of inventories, the types of assistance needed in obtaining reconversion to other lines of production and decisions as to what kinds of war contracts and whose war contracts are to be continued when production is cut back or hostilities are ended." To study the entire question of contract termination, Senator Reynolds thereupon appointed a War Contract Subcommittee in the Senate Military Affairs Committee, composed of Senator Murray, Chairman, Senator Harry Truman of Missouri, and Senator Chapman Revercomb of West Virginia. Under the direction of Senator Murray, the Subcommittee proceeded to initiate a broad study of the problems involved in contract termination.

Nevertheless, it was not until September, r943, that Government agencies or American businessmen came to realize that the basic policies to be followed in contract termination were subjects of Congressional determination. This fact was brought home for the first time by the now historical letter of September 20, from Lindsay C. Warren, the Comptroller General, to Senator Murray. Replying to Senator Murray's request for comment upon his preliminary report concerning 
mandatory advance payments, Mr. Warren took the occasion to voice vigorous criticism not only of Senator Murray's proposals but also of the termination regulations of the War Department and of the proposed uniform termination regulation being developed by the War Production Board. Specifically, Mr. Warren charged that settlement of termination contracts by the contracting agencies would result in untold waste of Government money, and submitted legislation that would give the Comptroller General full authority over the making of final settlements on terminated contracts. Although Mr. Warren's letter did not touch upon many of the most fundamental issues involved in contract termination, it served the purpose of dramatizing the need for legislative action. Since then the center of interest has rapidly shifted to the Congressional arena. New bills have been introduced: one by Senator Murray and Congressman Wright Patman of Texas, Chairman of the House Committee on Small Business, directing the Smaller War Plants Corporation to make termination loans to smaller companies, one by Chairman Carl Vinson, of the House Committee on Naval Affairs, introduced at the request of the Navy Department, and finally an "omnibus" contract termination bill sponsored jointly by Senator Murray and Senator George." Extensive hearings, some of them featuring sharp clashes between opposing personalities and opposing philosophies, have been held by the House Committee on Military Affairs, the War Contract Subcommittee of the Senate Committee on Military Affairs and the Senate Special Committee on Post-War Planning, headed by Senator George.

The hearings and discussions held to date reveal that there are four major problems involved in contract termination:

I. The settlement of claims on terminated contracts.

II. Putting released resources back to work.

III. The pattern of terminations.

IV. Governmental organization.

In the summer of I943 only part of the problem of contract settlement-namely, interim financing through advance payments or loans-was regarded as within the scope of Congressional interest. Later, it soon became evident that interim financing could not be separated from the problem of final settlement, and that the problems of settlement could not be separated from the problem of appraising and disposing of the materials released through termination, from the decision as to how many contracts and whose contracts are to be terminated, or from the question as to what type of Government organization is needed to administer the entire program. At the present moment, there is still considerable doubt in the minds of many members of the Congress and other students of the problem as to precisely where the line should be drawn between the Congressional and the executive determination of major policies. It is becoming increasingly clear, however, that all aspects of the problem are susceptible, in some degree, to legislative treatment and that

\footnotetext{
${ }^{2}$ An analysis of this bill will be made by the writer in Part II of this symposium, shortly to be
} published. 
without legislative directive many aspects of the program can never be administered effectively.

\section{The Setrlement of Claims on Terminated Contracts}

The basic aims of contract settlement should be (I) to obtain quick, final settlements that are fair to both the contractor and the Government, and (2) to provide liberal interim financing, where and to the extent it is needed, during the period between the termination of a contract and final settlement. These aims should be clearly set forth in a legislative declaration of policy that it is the right 'of all companies with claims resulting from war contract terminations, whether they be prime contractors, subcontractors or suppliers, to obtain quick, equitable final settlements and liberal interim financing and that it is the responsibility of the Government to see that this right is made effective.

\section{Final Settlement}

There are seven basic questions in contract settlement that seem to call for legislative answers.

The first, and most obvious, is: "How should the specific amount to be paid by the Government on a contract termination claim be arrived at?"

One of the unfortunate by-products of the struggle for power between the contracting agencies and the Comptroller General has been the specious theory that the former would arrive at the amount to be paid by way of "negotiation" and the latter by way of "audit or formula." This theory is based on a sublime disregard for the facts of life. Obviously, a "negotiator"-in addition to exercising his judgment and doing a little bargaining-must look for certain facts and adhere to certain rules of the game. An "auditor" does not merely copy certain figures from the books, set them up on a tabulating machine and push a button; he must also use a little judgment and do a little bargaining, albeit only with his conscience. All settlements on termination claims must result from a combination, in varying degrees, of both negotiation and audit.

All of the various "uniform termination clauses" that have been proposed and are being developed indirectly recognize this fact. Although settlement by negotiation is set forth as an alternative to settlement by formula and although negotiation is plumped for as the best way of doing the job quickly, the allowable costs and the definitions included in the formulae are clearly supposed to provide a general basis for the negotiation. The major reason why this has not been stated explicitly in such termination clauses is the fear that the Comptroller General would attempt to reopen the settlements to see if they properly adhered to the formulae. Statutory limitations upon the review functions of the Comptroller General, as proposed in the Murray-George bill, will clarify this question and allow the Government's termination clauses to set forth clearly that all settlements, whether agreed upon between the two parties or determined unilaterally by the contracting agency, will be based upon some set of principles or formulas. 
There is considerable question as to how far Congress should go in spelling out the specific cost principles upon which settlement should be based.

The Murray-George bill states that "it is the policy of the Government to insure to every war contractor (defined to include subcontractors and suppliers) fair compensation for the termination of any war contract." It also states that such fair compensation should include (I) reasonable expenses incident to termination and settlement, (2) reasonable expenses of removing and storing materials, (3) a reasonable profit on the work done on the uncompleted portion of the contract and (4) 3 percent interest on the amount due, starting 60 days after filing of the claim and ending upon final settlement. Beyond this, the Murray-George bill delegates to the executive branch the responsibility of setting forth the policies that guide settlement. The contracting agencies are told to "establish methods, suitable to the conditions of various classes of war contractors, for determining fair compensation for the termination of war contracts on the basis of actual, standard, average, or estimated costs, or of a percentage of the contract price based on the percentage of completion of work under the terminated contract, or on any other basis."

Some manufacturers have proposed that a full list of allowable charges be included in the legislation, in addition to the four listed above. Otherwise, they maintain, contracting officers will feel that there is insufficient Congressional backing for the authorization of certain disputed charges. The procurement agencies, on the other hand, contend that such a list would make for rigidity, that no list could ever be complete and that items left off the list would tend to be disallowed.

The question of how to arrive at the amount to be paid is inextricably tied up with the second basic question concerning final settlement: "What is the Government's responsibility toward the claims of subcontractors and suppliers?"

The present system of settling with subcontractors may well be compared to the old-fashioned bucket brigade method of putting out a fire, where buckets were passed up the line from the man that stood near the well to the man that stood near the house on fire. In many cases there are five or ten hands through which a subcontractor's claim must go before it can reach a contracting agency. The original claim often has to pass from a sub-subcontractor in Peoria, to a subcontractor in Hartford, to a prime contractor in Philadelphia, with the accompanying disadvantages flowing from the geographical distances involved and the absence of personal contact. Each time the bucket is passed, another set of accountants is usually called in to make a new examination before allowing it to go up the line. Often it will be impossible for the man in Hartford to know whether the claim really goes to Philadelphia or whether it goes to another company in St. Louis from which it has obtained work. Despite the Government lawyers who maintain that this system is workable, the industrial economy of America was not built in such a way that one can easily unravel the subcontracting maze and tell whether the machinery or materials supplied by the manufacturer in Peoria to the manu- 
facturer in Hartford are being used for Navy Contract I23-ABC or Army Contract $456-\mathrm{DEF}$.

Moreover, in many cases the man in Hartford or Philadelphia may be completely uninterested in worrying about the Peoria claim anyway or, if he gets paid on it, in passing the money down the line to Peoria. Furthermore, after Germany is beaten, and especially after the defeat of Japan, many little men in the bucket brigade-and some big ones also-will close up shop. Their subcontractors will then have no place to go with their claims. They will be termination orphans in the post-war storm.

At the present moment, contracting agencies stipulate that they will reimburse prime contractors on their settlements with their first-tier subcontractors only if the settlements are approved in advance by the contracting officer. This further complicates and slows down the process. In recognizing their responsibility to protect the Government against overpayment, the contracting agencies have not developed any better way of exercising that responsibility than through the inflexible, mechanical process of prior approval. They have failed to realize that their responsibility on contract termination is indivisible and that protection of the Government's genuine interest is an idle dream unless, at the same time, they fully exercise their responsibility to provide quick, final settlements that are fair to the subcontractor.

The defenders of the present system charge that its critics are asking the Government to deal with all subcontractors directly. Such a proposal would be administratively impossible and legally out of the question. In fact, it has never been advanced by anyone except those who are looking for a straw man that can easily be knocked down.

The only genuine alternative to the present system would have to be built on the basis of a statutory delegation to the contracting agencies of the unmistakable responsibility to provide war contractors and suppliers with the opportunity to obtain quick, equitable settlements on subcontracts and purchase orders. Once this mandate is given, a variety of implementing policies can be developed-some in the statute, some administratively. For example, the contracting agencies could cooperate with the larger prime contractors in helping develop the policies and procedures to be followed by the companies' termination departments, especially with regard to their dealings with subcontractors. One of the arguments for this approach is the fact that the cost of operating these termination departments will be included in a company's allowable termination expenses and paid for by the Government. If this is done, moreover, the contracting agencies will be able to place more confidence in the operations of the prime contractors and relax their present requirements for prior approval of settlements with first-tier subcontractors. The Aeronautical Chamber of Commerce has proposed that the legislation "include authority for a prime contractor, acting in good faith, to make final settlement, in any amount not exceeding $\$ 25,000$, of any subcontract." Irrespective of any specific figure below which prior approval would be ruled out, by legislation, Con- 
gress should also specifically authorize the contracting agencies to waive prior approval on larger amounts.

On the other hand, the contracting agencies must be realistic enough to understand that many prime contractors will be unwilling or incapable to carry on termination negotiations with all their subcontractors. The agencies must therefore gear themselves to the necessity of dealing directly with subcontractors in all tiers. It will be futile for them to hide behind the skirts of legal purity and proclaim that they cannot breach their contractual relations with the primes. On the one hand, they can obtain the consent of the prime-and, in fact, most cost plus contracts now call for the Government's settling with subs. On the other hand, they can purchase a sub's claim. While the latter is somewhat unorthodox, both methods are entirely legal.

Representatives of the contracting agencies have at times conceded that the contracting agencies should be required to purchase the claims of all subcontractors whose primes have been declared insolvent by a court of competent jurisdiction. However, it is evident that if you wait until a court makes up its mind, the subcontractor might very well be extinct before the prime is officially labelled insolvent. The legislation should provide complete protection for any subcontractor whose prime is insolvent, irresponsible or out of business and who may therefore become a termination orphan. This would undoubtedly include, among other things, the purchase of claims by the contracting agencies on a much broader basis than the officially-declared insolvency of the prime. The subcontractor might also be given (as was provided in Section 4 of the Dent Act in 1919) a prior lien on any settlement funds paid to the prime.

The legislation should also provide that payments to subcontractors be subject to such control by the contracting agency as will assure receipt by the subcontractor as soon as the prime contractor is compensated. It should give the subcontractor the right to appeal to the contracting agency against the decisions or indecision of his prime contractor.

Third, there is this question: "Must all claims be handled directly with the contracting offices that originally awarded the contract?"

If the answer is in the affirmative, settlement procedures will bog down in a mass of complications. The prime contractor in San Antonio, Texas, will have to rely on the mails and the long distance telephone for contact with the Quartermaster's Office in Philadelphia. The manufacturer who is performing similar work for the Ordnance Department, the Signal Corps, the Army Air Forces and the Chemical Warfare Service will have to negotiate with four different branches of the War Department. The manufacturer who is supplying similar products to the War Department, the Navy Department and the Maritime Commission will have to deal with three entirely different agencies.

It seems clear, therefore, that Congress should direct the contracting agencies to work toward settling a manufacturer's claim in his own home town, nego 
tiating agency-wide settlements and developing Government-wide settlements by assigning particular companies to the agency from which it has obtained the most work. There might also be mandatory provisions calling for agency-wide or Government-wide settlements, insofar as prime contracts are concerned, at the option of the prime contractor.

Company-wide settlements are more difficult, since they would usually call for settling claims on a company's subcontracts together with its prime contracts. Nevertheless, the agencies should be told to develop a full-fledged experimental program aimed at allowing a company to obtain settlements from one office, at regular intervals, of all its termination claims. On the basis of experience it may prove possible to use the company settlement to deal with general cut-backs within a given program.

The fourth question is one that is uppermost in the minds of all war contractors: "How can uniformity and simplicity be achieved?"

- It will be a decade before the average American manufacturer-especially the little man-recovers from his resentment against the avalanche of duplicating and needlessly complex wartime reporting forms that descended upon him after Pearl Harbor. Accordingly, he has good reason to fear what may happen when termination notices start coming thick and fast. And with good reason! The preparation of settlement procedures and accounting records offers a spendid opportunity for each agency and for thousands of minor officials to give free rein to their creative fancy in the development of more and more complicated regulations and forms. As things ordinarily go, no contracting or disbursing official will ever be accused of neglecting the Government's interest if he insists upon additional records and more accounting nuances.

It will be impossible to cope with this problem unless Congress gives somesingle agency the responsibility of developing the major administrative policies. under contract termination legislation and thereby guiding the activities of the contracting agencies. The first job of such an agency would be to develop a uniform termination regulation and a uniform termination clause for insertion in prime contracts. Special emphasis must also be laid upon termination clauses in subcontracts, as was indicated in the following statement of Albert M. Carter, Acting Chairman of the Smaller War Plants Corporation, before the War Contract Termination Subcommittee:

"The scanty information available so far indicates that the majority of subcontracts: do not contain termination clauses. Some subcontracts have incorporated by reference the termination clauses contained in the prime contracts in connection with which they have been let; and a few subcontracts contain termination clauses exceedingly disadvantageous to the subcontractors, placing practically the entire burden of losses in con-nection with contract termination on the subcontractor. It has been reported that in: some instances subcontractors who have accumulated substantial inventories for the expeditious performance of their subcontracts, would not be entitled under their termination clauses to more than the scrap value of such inventories. . .." 
Above all, it should be recognized that uniformity and simplicity are the products of a well-conceived program. They cannot be attained without legislation that squarely faces all the other basic questions in contract settlement, and without a flexible and imaginative administration.

Congress should pay special attention to the fact that there are tremendous variations among manufacturers in their record-keeping and accounting methods. A clear policy should be set forth that "the accounting practices regularly followed by the contractor shall be utilized so far as is consistent with this Act." Otherwise, there is the danger of over-rigidity and too much detail in the various forms and reports that will have to be filled out under any uniform regulations.

The fifth question is: "What kind of appeals system should be provided?"

As already suggested above, the subcontractor should have the right to appeal to the contracting agency over the head of the prime contractor. In addition, Congress should direct the contracting agencies to establish contract settlement appeal boards to deal with appeals over the head of the official responsibility for a particular settlement. When a war contractor cannot find satisfaction within a contracting agency, he should be given a choice of going to an inter-agency appeals board or to the courts. While the contract settlement program should aim at minimizing litigation, resort to the courts should be rendered less terrifying by expanding the personnel and streamlining the operations of the Court of Claims. The contractor could also go to Congress and ask for amendments in the legislation or request an investigation of administrative practices that seem to violate the spirit of the existing law.

The sixth question is one that has already received considerable attention in public debate: "How can the Government protect itself against overpayment, waste and fraud in connection with contract settlements?"

In answering this question the old adage "an ounce of prevention is worth a pound of cure" might well be rephrased as follows: "One good contract settlement program is worth an army of reviewers, investigators and post-auditors." The best protection against waste of the Government's money, whether through accident or through intent, will be an efficient, well-coordinated system of contract settlement based on legislation that sets forth basic policies and standards. In addition to a sound contract termination statute, this calls for a Congressional determination of policy on the appraisal of surplus materials. Otherwise, it will often be impossible to tell whether a particular appraisal is super-conservative or lavishly generous.

Naturally, there is also an important role for adequate records and for certain types of post-settlement checks on such records. Any over-all office that supervises the contract settlement operations of the contracting agencies should constantly review a selected sample of contract settlements as a guide in the development of future policies and procedures. While it should not be in a position to over-rule a settlement once it has been made, it would turn over to the Department of Justice any cases of suspected fraud or illegality. The Comptroller General should 
also review all payments to see that they are in accordance with the negotiated agreements. To the extent that he discovers suspected overpayments included within the agreements, he should be given the statutory responsibility of reporting such cases to the agency involved, to the Department of Justice or to the proper committees of Congress. In order to properly handle the cases that are brought to it, the Department of Justice might well be required to elevate its present War Frauds Unit to the status of a division and expand its personnel. In the case of the larger companies, an additional check-up will also be provided by the regular renegotiation functions of the Price Adjustment Boards.

Question number seven is: "What shall be the status of informal commitments?"

In the early days of the war effort the wheels of production were often set in motion by phone calls, telegrams or letters, without waiting for the formal ceremony of a contract award. Sometimes, for one reason or another, such work has continued until the present without benefit of clergy. Informal contracts of the same type are still resorted to despite official frowning upon their use.

A similar situation existed after the last war. In rgrg, the Dent Act was passed to provide for the recognition of such informal commitments as formal contracts. Legislation of the same general type is needed today, but care should be taken that it discourages the further use of informal commitments and encourages their rapid conversion into formal contracts.

\section{Interim Financing}

There are several major methods that may be used to provide a war contractor with quick cash while waiting for final settlement: production advances, termination advances, guaranteed loans and direct loans. The official philosophy of the contracting agencies-as distinguished from the privately-expressed convictions of many of their employees-has been that Congress need only strengthen their present powers in connection with these methods. The contracting agencies will then be able to cope with the situation and see that everybody is happy.

Should Congress adopt this philosophy, it will automatically be consigning thousands of war contractors to a shaky start in the reconversion race, if not to bankruptcy. While at first glance it might seem that with so many techniques to choose from a contracting agency should be able to meet the needs of any company, in actuality the agency would be in the position of a man who tries to pick up a handful of gravel without bringing his fingers together. Most of the graveland especially the smaller stones-will slip through. Moreover, in this particular case, a few of the fingers happen to be extremely weak or are rheumatic at the joints and cannot be bent. The Murray-George bill wisely approaches this problem by stating that "it is the policy of the Government to insure adequate interim financing, within thirty days after application therefor, to every war contractor having a termination claim or claims." The Director of Contract Settlement is told to prescribe methods whereby all contractors, both prime and sub, will receive at least 
go percent of their claims. He is also required to prescribe the evidence that must be submitted in support of claims for interim financing and "the classes of cases in "which such interim financing shall be refused." In other words, while recognizing that manufacturers should not simply be paid 90 percent of anything they may care to ask for, the bill establishes a clear policy of paying at least 90 percent of what may reasonably appear to be due, within thirty days. The choice of the particular methods to be used-advances, direct loans, or guaranteed loans-is up to the executive branch.

The bill implements this policy by making production advances available for termination financing, and by fully authorizing partial payments up to Ioo percent and direct and guaranteed loans by the contracting agencies, the Smaller War Plants Corporation and the Reconstruction Finance Corporation. Excess payments are to be repaid at a high penalty interest rate.

Recently, considerable attention has been given to the use of $\mathrm{V}$ loans-that is, bank loans guaranteed by the contracting agencies under Executive Order 9112, of March 26, 1942-as a means of termination financing. When the $\mathrm{V}$ loan system was first instituted, a standard contract provision was developed that provided for the automatic suspension of interest and amortization payments upon termination of the borrower's war contracts. This means that the borrower is automatically supplied with working capital during the period between termination and final settlement (unless, as has happened, the loan itself is cancelled). On September I, 1943, the contracting agencies and the Federal Reserve Board announced the creation of a new loan, which was immediately baptized the "VT loan." The only difference between a VT loan and a V loan is that while the purpose of the former is to provide working capital for war production, the latter is authorized even though a company has no need for working capital and enters into the loan agreement merely to provide insurance against being strapped for money upon contract termination. This arrangement is regarded as entirely within the spirit of the executive order, since interim financing of war contractors with termination claims contributes to a company's ability to perform on other war contracts. However justified this interpretation may be, it is universally agreed that new legislation is needed to authorize a guaranteed loan of this type-what is called a "T Loan"-after a termination notice has been received. The War Department has therefore proposed legislation that would specifically authorize the contracting agencies to guarantee loans "for the purpose of financing any contractor . . . who is or has been engaged in the performance of any contract or operation deemed by such department or commission to be connected with or related to the prosecution of the war, and who is deemed by such department or commission to have rights in connection with the termination in whole or in part of any one or more such contracts or operations."

In his letter of October 30 to Senator Murray, ${ }^{2}$ Lindsay Warren, the Comp-

${ }^{2}$ Hearings before a Subcommittee of the Committee on Military Affairs on S. 1268, S. 1280 and S. 1. Res 80, 78th Cong., Ist Sess. (Nov. 4, 1943) 242. 
troller General, pointed out an obvious loophole in this proposal. He showed that type of legislation would not limit a guaranteed termination loan to the extent of the claims under the terminated contracts but would leave the door wide open to the guarantee of loans totaling far more than the amount of a contractor's claim. In other words, the War Department proposal would clearly allow the war appropriations of the contracting agencies to be used, at their discretion, in financing the reconversion of individual companies to peacetime production. Naturally, this goes far beyond the limited question of interim financing of terminated contracts. If Congress decides to use military appropriations for general reconversion financing (which would seem to be an unsound policy), it should do so only after a very thorough examination of the entire reconversion problem and after setting forth a very explicit set of policies and standards. With regard to termination loans as such, it should be required that these loans expire upon settlement of the terminated contract.

In providing for guaranteed loans, however, it will not suffice merely to remedy this glaring defect in the War Department's proposal. The most important problem is how to establish the guaranteed termination loan in such a way as to make it readily accessible to a larger group of borrowers than the $V$ loan has served in the past. To date, under the V loan system, there have been only 4,700 loans (and a smaller number of borrowers) amounting to only $\$ 5.4$ billion in total loan authorizations. Of the total amount authorized, only $\$ 1.7$ billion-or about 30\%-has actually been drawn upon. In many industries, such as aircraft manufacture, it has been extremely difficult for any company to get a $\mathrm{V}$ loan under adequate terms. In shipbuilding there is only one company now operating under a $V$ loan. Only two-tenths of one percent of all $\mathrm{V}$ loans authorizations consist of loans of less than $\$ 100,000$, whereas $90 \%$ of the loan authorizations has been comprised of loans of over a $\$ \mathrm{I}$ million. Moreover, companies whose balance sheet does not impress the bankers too favorably have been burdened with unnecessarily oppressive conditions in their loan agreements-such as the assignment of life insurance policies, the strict control of salaries, the provision that no investments can be made without the bank's approval, etc. Companies with reassuring balance sheets, on the other hand, often have to put up with many months of protracted negotiations.

One of the basic reasons for the present shortcomings of the $\mathrm{V}$ loan system is the fact that every $\mathrm{V}$ loan is the product of negotiations between at least four parties: the contracting agency that makes the guarantee, the bank that lends the money, the borrower and the Federal Reserve Board, which acts as the agent of the contracting agency. Often, one bank is legally unable to lend as large an amount as is called for and a pool of banks is formed. When this happens, the lawyers of each bank pitch in for all they are worth, the red tape mills start humming and times goes by. Although, in the original conception of the $\mathrm{V}$ loan, the Federal Reserve Board was supposed to act merely as an agent, it now makes a detailed report on a large number of cases and submits specific suggestions for 
provisions in the loan agreements. No general restrictions on loan agreement provisions are laid down for a bank to follow, with the result that it has free rein to write into a loan agreement any conditions that anyone of its vice presidents can dream up. At the root of these problems, of course, is the fact that there is quite a substantial risk involved in a V loan, despite the guarantee. The executive order coped with the risk factor by definitely authorizing guarantees up to $100 \%$ of the amount of the loan. However, in administering the executive order, the procurement agencies have shied away from the responsibility involved in making 100\% guarantees. In fact, they have adopted an inflexible rule of trying to sell the banks on smaller guarantees. While this is a worthwhile aim to the extent that it increases the flow of private capital into war production, in actual practice it has tended to im. pede the flow of private capital. In many cases, without a too\% guarantee, the bank is not justified in making a $V$ 'loan. In other cases, where it makes a loan, it counterbalances a guarantee that is too low with loan agreement conditions that are too oppressive. Accordingly, if $\mathrm{V}$ loans are to be used more extensively, the legislation must do far more than authorize the contracting agencies to make guarantees, but must also specify the terms and conditions under which such authority should be used.

However, no matter how actively and intelligently the V loan is pushed, it is obvious that it cannot meet the interim financing needs of the great majority of subcontractors and suppliers and that some form of direct Governmental loan will also be required. Senator Murray has proposed that direct loans on terminated contracts be made to smaller companies by the Smaller War Plants Corporation. Legislation of this type is unquestionably necessary. It would be dangerous, however, to limit the termination lending of the Smaller War Plants Corporation to specific claims. Rather, the Smaller War Plants Corporation should be authorized to make character loans as well-that is, to advance termination funds to a smaller contractor even before he has been able to identify and estimate all of his particular claims.

Congress should also spell out the specific role of the Reconstruction Finance Corporation in termination financing. It is entirely possible that this organization can perform the same direct loan functions for the bigger companies that the Smaller War Plants Corporation can perform for the smaller companies. Moreover, in both the case of the Reconstruction Finance Corporation and the Smaller War Plants Corporation, Congress should specifically direct that outstanding agreements on all production loans should be amended to include the suspension of interest and amortization payments upon contract termination. This would provide the present borrower from either of these two agencies with the same protection that is now afforded to the present borrower under the $\mathrm{V}$ loan system.

A number of miscellaneous legislative measures to ease the working capital situation of the company with terminated contracts have also been suggested. One proposal calls for a moratorium on a company's pending renegotiation pay- 
ments until its claims on terminated contracts are finally settled. Another calls for the acceleration of refunds under the carry-back provision of the r 942 tax laws. Both of these suggestions, with the appropriate safeguards, might well be incorporated into the next revenue act.

\section{Putting Released Resources Back to Work}

Whenever a contract is terminated, materials and manpower that had been allocated for work on the contract are released. At the present moment, most companies with terminated contracts are able to absorb the released manpower and the released materials in their regular production programs. However, there are already many companies where terminated contracts result in a sharp disruption, either temporary or long-standing, in their productive effort. In these cases, there is already a serious problem of how to get the materials and manpower to the place where they can best be used.

Insofar as materials are concerned, present procedures of contract settlement constitute an almost impassable barrier. The company cannot dispose of materials until it is given a minimum price at which the sale can be made. At times, the precise details of finding and choosing between buyers has had to be passed upon by higher tier contractors and various officials of the contracting agencies involved. More and more businessmen have despaired of being able to dispose of such materials quickly and have centered their attention on thinking up ways of getting such materials out of their plant. As a result, there has developed a concerted and well-justified demand that if the Government has not arranged for the disposal within 30 to 60 days, the manufacturer be given the right to remove and store such materials at the Government's expense. While this right should unquestionably be conferred upon the manufacturer by statute, Congress will never be able to come to grips with this problem until it also lays down policies to be followed in appraising the materials and in getting them back to use. Perhaps the manufacturer-in exchange for being given the right to remove and store the materials at the Government's expense-should be obliged to inform the Redistribution Division of the War Production Board, or any subsequent office with the same function, concerning all materials released through contract termination. The Redistribution Division would then have the responsibility of seeing to it that the materials went where they are needed. This is one of the many aspects of the contract termination problem that could never possibly be effectively handled through the bucket brigade system of passing inventory material lists up through the sub-sub and subcontractor to the prime contractor and hence to the Government. On this problem at the very least, no matter what is done with respect to final settlement, the Government must realize that unlike the Lowell's and the Cabot's, who are said to speak only to God, the Government often has to get off its high legalistic horse and deal directly with the hoi polloi of subcontractors and suppliers.

A similar problem exists with regard to workers no longer needed as a result of contract termination. Prime or subcontractors who release employees as a result 
of contract terminations should inform the local U. S. Employment Service office concerning the employees released. Moreover, in order to facilitate the re-entry of such employees into production, dismissal wages up to one month's regular pay might be allowed as a termination cost chargeable to the Government.

The problem of released facilities-machinery and factories-is so complex that separate treatment would be needed even to enumerate the major problems.

\section{Pattern of Terminations}

How much production, within any given war program and at any given time, should be cancelled?

Once it is decided how much to curtail a program, whose contracts should be chosen for cancellation?

Once it is decided to cancel a given contract, should work be stopped at once or should it be allowed to taper off slowly?

The answers that are worked out for these questions will determine not only the pattern of contract terminations but also the pattern and rate of industrial demobilization.

In the early stages of the war one of the most difficult tasks before the war agencies was to come to an agreement upon the precise character of military requirements. Many fierce battles raged between the various war agencies on the projected size of the war program as a whole and upon the allocation of critical materials to specific munitions programs. As we pass over the hump in war production and come closer to the transition period, the same problem of determining requirements is again coming to the fore. This time, however, it will be less and less a question of what new contracts to award and more and more a question of what old contracts to cancel. At present the fundamental factors in cancellation requirements are the shifts in production occasioned by changing theatres of operation and the obsolescence of older types of material, the practical completion of the initial equipment of the armed services and the presence of adequate reserves in many types of equipment and supplies. After the collapse of Germany, there will be the additional question of whether or not to fight a fast war against Japan or a slow one. After the fall of Japan, there will be the question of whether we should demobilize quickly or slowly, of how big a post-war army, navy, air force and munitions industry is needed, and of how far we will go in the relief and rehabilitation of other countries.

Obviously, some of these questions involve profound problems of military strategy, national politics and international relationships and will be determined by act of Congress, by treaties ratified by the Senate, by Presidential decision, and by the joint chiefs of staff. From the viewpoint of this article, however, it will suffice to point out that there is as yet no existing machinery for the planned determination of whether we will demobilize slowly or rapidly and how we will demobilize in either case. From the viewpoint of contract termination per se, this is fundamental. Obviously, if all contracts are allowed to continue until completion, the 
intricate problem of contract settlement will be completely sidestepped. During the coming months, many particular industries and many individual companies will fight. for such a policy insofar as it relates to their own operations. It is essential that a question of as great importance as this one be dealt with by the Congressif only to establish an interim. planning agency that will act as a clearing house on cancellation requirements, and that will administer any specific cut-backs that may be called for in appropriation measures or other laws. Moreover, Congress should provide clear authority for the pooling or transfer of war contracts among Government agencies. A manufacturer making pants for the Quartermaster should be able to continue operations under that contract in order to supply the same product to the Foreign Economic Administration of the State Department.

Once the volume and timing of contract terminations are decided upon the question still remains as to how the particular contracts to be terminated should be chosen. This involves a choice between areas-such as whether or not an area where the labor supply is critically short should have its contracts terminated first. It involves a choice between industries-such as whether the tank program of the locomotive industry or the tank program of the automobile industry should first be cut. Within an area and within an industry it involves the question as to which company should first be cut or whether they should all be cut by an equal proportion at the same time.

Each of these questions is fraught with complications. Some industries, some areas and some individual companies will find it to their interest to be terminated quicker than others-since that would help them get off to a head start in civilian production. Other industries, areas or individual companies will want to be terminated last-since that might help them continue in business during the critical period of transition between war and peace. Here again is a province within which legislation of a high statesmanlike character is clearly called for. Without such legislation the executive agencies will have the power of life or death over entire areas of the country, entire industries and thousands of individual business enterprises. It must be kept in mind that at the present moment, these agencies have a responsibility toward winning the war and that is all. They have no responsibilities with regard to the transition from war to peace, and should not be expected to assume or carry out such responsibilities without a clear mandate from the Congress.

Congress should also determine the general policies to be followed in the issuance of termination orders. A flood of "stop work at once" orders after the defeat of Germany or the defeat of Japan would militate against orderly contract settlement and orderly demobilization. To the fullest extent possible, thirty days of advance notice should be provided before cessation of work under a terminated contract. Moreover, it should be the Government's policy to allow, and at times require, the further continuation or the completion of certain items-such as semi-finished component parts and civilian-type goods. This calls for widespread consultation with 
prime contractors before and after receipt of termination notices and a joint approach toward the problem of the termination notices sent down the line to the various subcontractors.

The resulting cost to the Government will mainly consist of the time and energy needed to plan an orderly approach to termination. The gains to the Government would bulk much larger. There would be a sharp reduction of contractor's claims against the Government and of the time and energy needed to settle such claims. The task of checking inventory records would be greatly simplified. There would be a more orderly release of labor. Many essential war and civilian items would be supplied more rapidly. Millions of dollars would be saved through finishing half-completed materials that would otherwise have nothing but a scrap value.

\section{Government Organization}

A large part of the current controversy over contract termination has centered around the question of who should have the power to make final settlements. The procurement agencies now have this power on lump sum contracts, while the Comptroller General has broad powers over payments on cost plus contracts. The Comptroller General has proposed that his powers be extended to the point where he has the authority to approve or disapprove all final settlements.

In resolving this controversy, it is to be hoped that Congress will neither perpetuate the present situation nor yield to the arguments of the Comptroller General. On the one hand, the statutory power of determining general administrative policies should be given to a new Office of Contract Settlement within the Office of War Mobilization which, without making final settlements itself, would operate largely through the contracting agencies. On the other hand, the Comptroller General should be given the responsibility of (I) post-checking on final settlements, (2) reporting his findings to Congress and the appropriate executive agencies and (3) advising the Director of Contract Settlement on administrative policies and procedures.

Specifically, the following duties and powers should be conferred upon the Director of Contract Settlement:

(I) to make all major decisions of administrative policy under this Act.

(2) to promulgate uniform policies, procedures, regulations and contract provisions to be followed by all the various contracting agencies in the termination and settlement of contracts, in guaranteeing loans, etc.

(3) to promote the integration of contract settlement policies with policies and programs of war production, demobilization, disposal of surplus war property and the renegotiation of war contracts.

(4) to establish policies and procedures to promote the settlement of terminated contracts, to the fullest extent possible, on an agency basis, on a Government basis and on a company basis.

(5) to promote the decentralization of contract settlement operations.

(6) to promote use of simple reporting forms that place no undue burden on recordkeeping and accounting personnel. 
(7) to work jointly with the Smaller War Plants Corporation in protecting the interests of smaller prime contractors and subcontractors in contract settlement.

(8) to direct the contracting agencies in the training of personnel competent to handle contract settlement problems.

(9) to cooperate with the contracting agencies in advising the major prime contractors on the organization of their contract termination departments.

(10) to provide businessmen with current information on termination policies and procedures.

(II) to establish a regular reporting system within each contracting agency on the progress of terminations, interim financing and settlement proceedings.

(I2) to report to Congress every three months on the exercise of each of its responsibilities and powers, on the operations of each of the contracting agencies under the Act and on the need for any additional legislation.

An organizational structure of this type, however, would be sufficient to cope with little more than the problems of settlement. In fact, in the absence of a complementary structure dealing with the putting of released resources back to work, the pattern of termination and other reconversion problems, the handling of contract settlement would itself be impaired. It is therefore essential that Congress enact legislation dealing with these related subjects also.

The recent activities of Bernard Baruch and others within the Office of War Mobilization on the problems of contract termination and reconversion clearly indicate the direction toward which Congressional legislation should be orientated. Since the war is still on, and since many bloody battles have yet to be fought, before even the collapse of the German front, it is essential that administrative policies on contract termination and reconversion be developed within the framework of the war production program itself. It would seem reasonable, therefore, that Congress should delegate specific responsibilities to the Office of War Mobilization, together with the powers needed to carry out such responsibilities, on the following basic points:

I. The coordination of over-all termination, as well as war production, requirements.

2. The settlement of claims on terminated contracts, through a special Office of Contract Settlement.

3. The disposal of surplus war property, through a special Office of War Surplus.

4. The allocation of materials and machinery, through the War Production Board or its successor.

5. Price control, consumer rationing and wage stabilization through the Office of Price Administration and the War Labor Board.

6. The demobilization of manpower, through the War Manpower Commission.

In addition to delegating responsibilities and powers, Congress should clearly recognize that its own responsibilities are not discharged when legislation is signed by the President and printed in the statute books. Without continuous Congressional vigilance, it is probable that insufficient attention would be given to the need for subsequent amendments. There is also a serious danger that the wrong type of 
administration would violate the aims of the legislation and create many scandalous situations for post-war investigating committees to dig up and expose.

But precisely how can the further responsibilities of Congress be discharged? Neither House as a whole can-or should-perform the necessary functions. Individual members can take only an individual approach. Why should not the job be done, then, through the same standing committees that report the legislation to the floor? Why should not the legislation itself fasten upon the appropriate standing committees of both Houses the responsibilty of currently appraising the administration of the legislation, studying all reports to Congress submitted thereunder and recommending from time to time amendments to the legislation and improvements in administrative policies and procedures?

In conclusion, the role of Congress in contract termination is to enact comprehensive legislation setting forth specific national policies as well as delegating powers and establishing the proper executive structure and to exercise effective surveillance over the administration of the legislation. As everyone knows, there are many people in all branches of the Government who strongly argue that Congressional action be limited to the delegation of certain powers not yet exercised by the executive agencies or to the creation of new administrative mechanism. There are still more who react violently against the thought of continuous Congressional vigilance. If Congress goes along with either of these philosophies, it will be thereby abdicating the position it should rightfully occupy. By avoiding both philosophies and properly discharging its responsibilities to the American people, Congress has the opportunity to lay the foundation not only for the sound handling of contract termination problems but for the effective functioning of the respresentative system in post-war America. 